\title{
POTENSI RETRIBUSI PASAR UMUM DI KOTA BENGKULU
}

\author{
Ahmad Soleh, Wagini, Vero Agustin \\ Program Studi Akuntansi Fakultas Ekonomi Universitas Dehasen Bengkulu \\ ahmadsolehse81@yahoo.co.id
}

\begin{abstract}
ABSTRAK
Ahmad Soleh, Wagini, Vero Agustin; Retribusi pasar merupakan pungutan yang ditarik oleh Dinas Perindustrian dan Perdagangan kepada wajib retribusi atas pengunaan fasilitas berupa los, kios dan pelataran yang diberikan oleh pemerintah kota Bengkulu. Penelitian ini bertujuan mengkaji potensi retribusi pasar umum di Kota Bengkulu. Teknik pengumpulan data dalam penelitian ini menggunakan dokumentasi. Data sekunder diperoleh dari Dinas Perindustrian dan Perdagangan Kota Bengkulu. Rumus potensi retribusi pasar digunakan dalam metode kajian ini. Hasil penelitian menunjukan bahwa potensi pasar yang ada di Kota Bengkulu mengalami fluktuasi. Rata-rata potensi penerimaan retribusi pasar umum sebesar Rp 2.220.464.960,- per tahun dengan rata-rata pertumbuhan sebesar 2,51\% per tahun. Hal tersebut seiring dengan realisasi retribusi pasar umum yang juga mengalami fluktuasi. Rata-rata realisasi penerimaan retribusi pasar umum sebesar Rp 1.854.906.535,- dengan rata-rata pertumbuhan sebesar 6,53\% per tahun. Persentase capaian realisasi terhadap potensi penerimaan retribusi pasar umum di kota Bengkulu secara berturut-turut dari tahun 2014 hingga tahun 2016 masing-masing sebesar $82,08 \%, 80,23 \%$ dan 88,07\% dengan rata-rata sebesar 83,53\% per tahun. Prestasi capaian rata-rata di atas $80 \%$ ini dianggap baik. Namun, pemerintah daerah kota Bengkulu harus senantiasa berupaya meningkatkan realisasi penerimaan retribusi pasar umum dengan potensi yang dimiliki.
\end{abstract}

\begin{abstract}
Ahmad Soleh, Wagini, Vero Agustin; Market Levy is a charge withdrawn by the Department of Industry and Trade to compulsory retribution for the use of facilities in the form of stalls, kiosks and courtyards provided by the city government of Bengkulu. This study aims to examine the potential of public market retribution in Bengkulu City. Data collection techniques in this study using documentation. Secondary data was obtained from the Office of Industry and Trade of Bengkulu City. The market retribution potential formula is used in this method of study. The results showed that the existing market potential in Bengkulu City fluctuated. The average potential of general market retribution is Rp 2,220,464,960 per year with an average growth of $2.51 \%$ per year. This is in line with the realization of public market levies that also experience fluctuations. The average realization of general market retribution revenue amounted to $R p$ $1,854,906,535,-$ with an average growth of $6.53 \%$ per year. The percentage of realization achievement of potential revenue of general market retribution in Bengkulu city from 2014 to 2016 were 82.08\%, 80.23\% and $88.07 \%$ respectively with an average of $83.53 \%$ per year. Achievement average achievement above $80 \%$ is considered good. However, the local government of Bengkulu city should always try to increase the realization of acceptance of public market retribution with its potential.
\end{abstract}

Key Words: Potential, Public Market Levy, Bengkulu City.

\section{LATAR BELAKANG}

Indonesia merupakan suatu negara kesatuan. Sebagai negara kesatuan, maka daerah merupakan bagian yang tak terpisahkan untuk melaksanakan pemerintahan. Setiap daerah yang disebut daerah otonom diberi wewenang oleh pemerintah pusat untuk mengurus rumah tangganya sendiri. Daerah kabupaten/kota memiliki kewenangan untuk membuat kebijakan daerah guna memberikan pelayanan kepada publik dengan baik, meningkatkan peran serta prakarsa dan pemberdayaan masyarakat yang bertujuan pada peningkatan kesejahteraan masyarakat. Untuk memenuhi semua pembiayaan daerah sendiri, setiap daerah harus dapat menghimpun dana sebesar-besarnya untuk pembangunan yang berkelanjutan. Pembangunan yang bertujuan pada peningkatan kesejahteraan masyarakata akan berjalan baik jika didukung biaya dan sumber daya manusia yang baik pula. Semakin besar pembangunan maka semakin besar biaya yang dikeluarkan. Untuk itu peningkatan sumber penerimaan daerah dipandang sebagai salah satu cara yang efektif untuk mencapai kesejahteraan masyarakat.

Sumber penerimaan daerah didapat dari hasil pajak daerah, hasil retribusi daerah serta hasil perusahaan milik daerah. Berdasarkan pada hasil penerimaan daerah tersebut, yang memiliki potensi besar pada kas daerah adalah pajak dan retribusi daerah. Pada prinsipnya retribusi sama dengan pajak. Berdasarkan Peraturan Pemerintah Nomor 28 Tahun 2009 tentang Retribusi Daerah, salah satu pungutan 
retribusi daerah adalah retribusi pasar. Retribusi pasar ini termasuk dalam retribusi jasa umum yang memberikan kontribusi yang cukup potensial terhadap peningkatan pembangunan dan kesejahteraan masyarakat. Untuk itu, pemerintah daerah harus benar-benar menggunakan hasil retribusi pasar dengan sebaik-baiknya. Salah satu usaha yang dilakukan oleh Pemerintah Daerah dalam mengelola retribusi pasar adalah memberikan pelayanan kepada masyarakat sesuai dengan apa yang telah mereka bayarkan kepada pemerintah. Keberadaan pelayanan ini dirasakan cukup penting sebagai aspek yang harus dilakukan dalam tatanan demokrasi di daerah itu sendiri. Pelayanan publik sebagai indikator utama bagi pemerintah daerah dalam menyelenggarakan pemerintahan harus dilaksanakan sesuai dengan peraturan yang berlaku dan dikelola dengan baik, karena pengelolaan retribusi pasar tidak dapat dilepaskan dari pelayanan yang diberikan. Namun, sebagian dari pengelolaan retribusi pasar selama ini belum sepenuhnya dirasakan oleh masyarakat pengguna jasa pasar.

Berdasarkan peraturan daerah kota Bengkulu Nomor 07 Tahun 2013 tentang Retribusi Pasar yang selanjutnya disebut retribusi adalah pungutan daerah yang dikenakan pada setiap pedagang yang memanfaatkan fasilitas pasar. Retribusi pasar memberikan peranan yang cukup untuk meningkatkan penerimaan retribusi daerah. Hal ini dikarenakan keberadaan pasar yang pasti ada di setiap daerah yang jumlahnya cukup. Di pasar tersebut pasti terjadi transaksi setiap hari atau pada hari-hari tertentu dan bagi para pihak yang melakukan transaksi tersebut dipungut biaya karena menggunakan pasar sebagai tempat transaksi. Retribusi pasar merupakan salah satu potensi pasar dalam meningkatkan penerimaan daerah. Dengan menganalisis potensi pasar kita dapat memperkirakan daya serapan konsumen terhadap produk/jasa yang hendak ditawarkan.

Permasalahan yang sering terjadi dalam menggali potensi pasar adalah kurang optimalnya penanganan di dalam pengolahan data guna mendapatkan potensi yang optimal. Sebagai contoh untuk menghitung potensi retribusi pasar perlu mengetahui komponen yang membentuk potensi daripada pasar itu sendiri. Komponen potensi pasar yaitu luas pasar (pelataran, kios, dan los), tarif yang dipungut, dan periode pemungutan (Mardiasmo, 2007). Menurut peraturan daerah Kota Bengkulu Nomor 07 Tahun 2013 pasar adalah fasilitas yang disediakan pemerintah daerah sebagai tempat kegiatan jual beli dan bongkar muat komoditi atau barang dagang. Terdapat beberapa pasar umum yang ada di Kota Bengkulu yaitu Pasar Panorama, Pasar Minggu, Pasar Baru Koto, dan Pasar Pagar Dewa. Pemilihan topik penelitian tentang kajian retribusi pasar umum di kota Bengkulu didasari oleh realita bahwa proporsi dari retribusi tersebut cukup besar sebagai salah satu sumber pendapatan daerah. Sehingga, kajian potensi retribusi pasar umum di kota Bengkulu dianggap penting untuk dilakukan.

\section{LANDASAN TEORI}

\section{Pasar dan Potensi Pasar}

Menurut peraturan daerah Kota Bengkulu Nomor 07 Tahun 2013, pasar adalah fasilitas yang disediakan pemerintah daerah sebagai tempat kegiatan jual beli dan bongkar muat komoditi atau barang dagang. Menurut Simamora (2008), pengertian umum pasar merupakan tempat di mana pembeli dan penjual bertemu dan berfungsi, barang dan jasa tersedia untuk dijual, dan terjadi perpindahan hak milik. Ada beberapa bentuk pasar yang umum yaitu sebagai berikut:

1. Pasar Persaingan Sempurna

Pasar yang terdiri dari banyak penjual dan banyak pembeli dengan produk yang seragam atau serupa (uniform), harga terbentuk melalui mekanisme pasar hasil antara penawaran dan permintaan sehingga penjual dan pembeli di pasar ini tidak dapat memengaruhi harga.

2. Persaingan monopolistik

Pasar terdiri dari banyak penjual dan banyak pembeli dengan harga yang beragam mulai dari yang paling rendah sampai yang paling tinggi. Keragaman harga ini disebabkan oleh adanya kesempatan untuk mendiferensiasi produknya. Dalam pasar yang seperti ini, sebuah perusahaan mempunyai kesempatan untuk menetapkan harga berbeda dengan harga produk lain asalkan menawarkan benefit (manfaat) yang berbeda. Pasar ini banyak dijumpai pada sektor jasa dan perdagangan eceran. Misalnya jasa salon, angkutan, dan toko obat/apotik.

3. Pasar Oligopolistik

Pasar yang terdiri dari sedikit penjual yang satu sama lain sangat sensitif terhadap strategi harga dan pemasaran perusahaan lain. Contoh industri yang termasuk dalam kategori ini adalah industri rokok, industri mobil, industri semen, jasa penerbangan dan lainnya.

4. Monopoli

Pasar yang terdiri dari hanya satu penjual. Contoh nya PLN, PDAM, dan Pertamina.

Pengertian pasar dikemukakan Mardiasmo (2007) adalah daya, kekuatan atau kesanggupan untuk menghasilkan penerimaan daerah atau kemampuan yang pantas diterima dalam keadaan seratus persen. Potensi penerimaan daerah dapat diukur dengan dua pendekatan yaitu berdasarkan fungsi penerimaan 
dan berdasarkan atas indikator sosial ekonomi. Sebagai contoh digunakan untuk menghitung potensi retribusi pasar perlu mengetahui komponen yang membentuk potensi daripada pasar itu sendiri. Komponen potensi pasar yaitu luas pasar (kios, los, dan pelataran), tarif yang dipungut dan periode pemungutan. Permasalahan yang sering terjadi dalam menggali potensi pasar adalah kurang optimalnya penanganan di dalam pengolahan data guna mendapatkan potensi yang optimal. Dalam perhitungan akurasi nilai potensi yang sesuai dengan kondisi lapangan sangat terkait dengan kelengkapan atau terjadinya variabel-variabel untuk menghitung potensi retribusi yang optimal. Untuk mendapatkan potensi yang maksimal dan realistis perlu diadakan pendataan, pemantauan lapangan, dan pengkajian yang cermat.

\section{Retribusi Daerah}

Menurut Siahaan (2010) retribusi daerah adalah pungutan daerah sebagai pembayaran atas jasa atau pemberian izin tertentu yang khusus disediakan dan/atau diberikan oleh pemerintah daerah untuk kepentingan orang pribadi atau badan.

1. Subjek Retribusi Daerah

a. Retribusi Jasa Umum adalah orang pribadi atau badan yang menggunakan menikmati pelayanan jasa umum yang bersangkutan.

b. Retribusi Jasa Usaha adalah orang pribadi atau badan yang menggunakan menikmati pelayanan jasa usaha yang bersangkutan.

c. Retribusi Perizinan Tertentu adalah orang pribadi atau badan yang memperoleh izin tertentu dari Pemerintah Daerah.

2. Objek Retribusi Daerah

a. Objek Retribusi Jasa Umum adalah pelayanan yang disediakan atau diberikan Pemerintah Daerah untuk tujuan kepentingan dan kemanfaatan umum serta dapat dinikmati oleh orang pribadi atau Badan.

Jenis retribusi jasa umum meliputi:

1) Retribusi Pelayanan Kesehatan

Pelayanan kesehatan adalah pelayanan kesehatan di Puskesmas, Balai Pengobatan, dan Rumah Sakit Umum Daerah. Dalam retribusi pelayanan kesehatan ini tidak termasuk pelayanan pendaftaran.

2) Retribusi Pelayanan Persampahan atau kebersihan

Pelayanan persampahan/kebersihan meliputi pengambilan, pengangkutan, dan pembuangan serta penyediaan lokasi pembuangan/pemusnahan sampah rumah tangga, dan perdagangan, tidak termasuk pelayanan kebersihan jalan umum dan taman.

3) Retribusi Penggantian Biaya cetak Kartu penduduk dan Akte catatan Sipil.

Akte catatan sipil meliputi akte kelahiran, akte perkawinan, akte perceraian, akte pengesahan dan pengakuan anak, akte ganti nama bagi warga negara asing, dan akte kematian.

4) Retribusi Pelayanan Parkir Tepi Jalan Umum

Pelayanan parkir di tepi jalan umum adalah penyediaan pelayanan parkir ditepi jalan umum yang ditentukan oleh pemerintah Daerah.

5) Retribusi Pelayanan Pasar

Pelayanan pasar adalah fasilitas pasar tradisional atau sederhana berupa pelataran, los yang dikelola Pemerintah Daerah, dan khusus disediakan untuk pedagang, tidak termasuk yang dikelola oleh Badan Usaha Milik Negara - Badan Usaha Milik Daerah dan pihak swasta.

6) Retribusi Pengujian Kendaraan Bermotor

Pelayanan pengujian kendaraan bermotor adalah pelayanan pengujian kendaraan bermotor sesuai dengan peraturan perundang-undangan yang berlaku, yang diselenggarakan oleh pemerintah Daerah.

7) Retribusi Pemeriksaan Alat Pemadam Kebakaran

Pelayanan pemeriksaan alat pemadam kebakaran adalah pelayanan pemeriksaan dan/atau pengizinan oleh Pemerintah Daerah terhadap alat-alat pemadam kebakaran yang dimiliki dan/atau dipergunakan oleh masyarakat.

8) Retribusi Pengujian Kapal Perikanan

Pelayanan pengujian kapal perikanan adalah pengujian terhadap kapal penangkap ikan yang menjadi kewenangan daerah.

b. Objek Retribusi Jasa Usaha adalah pelayanan yang disediakan oleh Pemerintah Daerah dengan menganut prinsip komersial yang meliputi:

1) Pelayanan dengan menggunakan/memanfaatkan kekayaan Daerah yang belum dimanfaatkan secara optimal; dan/atau 
2) Pelayanan oleh Pemerintah Daerah sepanjang belum disediakan secara memadai oleh pihak swasta.

Jenis Retribusi Jasa Usaha adalah:

a) Retribusi Pemakaian Kekayaan Daerah

Pelayanan pemakaian kekayaan daerah antara lain pemakaian tanah dan bangunan, pemakaian ruangan untuk pesta, pemakaian kendaraan/alat-alat berat/alat-alat besar milik daerah, sedangkan yang tidak termasuk dalam pengertian pelayanan pemakaian kekayaan daerah adalah penggunanan tanah yang tidak mengubah fungsi dari tanah tersebut, seperti pemancangan tiang telepon atau listrik maupun penanaman/pembentangan kabel listrik/telepon di tepi jalan umum.

b) Retribusi Pasar Grosir atau Pertokoan

Pasar grosir atau pertokoan adalah pasar grosir dengan berbagai jenis barang, dan fasilitas pasar/pertokoan yang dikontrakkan yang disediakan/diselenggarakan oleh Pemerintah Daerah, tidak termasuk yang disediakan oleh Badan Usaha Milik Daerah dan pihak swasta.

c) Retribusi Tempat Pelelangan

Tempat pelelangan adalah tempat yang secara khusus disediakan oleh pemerintah daerah untuk melakukan pelelangan ikan, ternak, hasil bumi, dan hasil hutan termasuk jasa pelelangan serta fasilitas lainnya yang disediakan di tempat pelelangan. Termasuk dalam pengertian tempat pelelangan adalah tempat yang dikontrak oleh Pemerintah Daerah dari pihak lain untuk dijadikan sebagai tempat pelelangan.

d) Retribusi Terminal

Pelayanan terminal adalah tempat pelayanan penyediaan tempat parkir untuk kendaraan penumpang bis umum, tempat kegiatan usaha, dan fasilitas lainnya di lingkungan terminal yang dimiliki dan/atau dikelola oleh Pemerintah Daerah. Dengan ketentuan ini, pelayanan peron tidak dipungut retribusi.

e) Retribusi Tempat Khusus Parkir

Pelayanan tempat khusus parkir adalah pelayanan penyediaan tempat parkir yang disediakan, dimiliki dan/atau dikelola oleh Pemerintah Daerah, tidak termasuk yang disediakan dan dikelola oleh Badan usaha Milik Daerah dan pihak swasta.

f) Retribusi Rumah Potong Hewan

Pelayanan rumah potong hewan adalah pelayanan penyediaan fasilitas rumah pemotongan hewan ternak termasuk pelayanan pemeriksaan kesehatan hewan sebelum dan sesudah dipotong yang dimiliki dan/atau dikelola oleh Pemerintah Daerah.

g) Retribusi Pelayanan Pelabuhan Kapal

Pelayanan pelabuhan kapal adalah pelayanan pada pelabuhan kapal perikanan dan/atau bukan kapal perikanan, termasuk fasilitas lainnya di lingkungan pelabuhan kapal yang dimiliki dan/atau dikelola Pemerintah Daerah, tidak termasuk yang dikelola oleh Badan usaha Milik Negara, Badan Usaha Milik Daerah maupun oleh pihak swasta.

h) Retribusi Tempat Rekreasi dan Olah Raga

Pelayanan tempat rekreasi dan olah raga adalah tempat rekreasi, pariwisata dan olah raga yang dimiliki dan/atau dikelola Pemerintah Daerah.

c. Retribusi perizinan tertentu

Objek Retribusi Perizinan Tertentu adalah pelayanan perizinan tertentu oleh Pemerintah Daerah kepada orang pribadi atau Badan yang dimaksudkan untuk pengaturan dan pengawasan atas kegiatan pemanfaatan ruang, penggunaan sumber daya alam, barang, prasarana, sarana, atau fasilitas tertentu guna melindungi kepentingan umum dan menjaga kelestarian lingkungan. Jenis Retribusi Perizinan Tertentu meliputi:

1) Retribusi Izin Mendirikan Bangunan

Izin mendirikan bangunan adalah pemberian izin untuk mendirikan suatu bangunan, termasuk dalam pemberian izin ini adalah kegiatan peninjauan desain dan pemantapan pelaksanaan pembangunannya agar tetap sesuai dengan rencana teknis bangunan dan rencana tata ruang yang berlaku dengan tetap memperhatikan Koefisien Luas Bangunan (KLB), Koefisien Ketinggian Banguan (KKB), dan pengawasan penggunaan bangunan yang meliputi pemeriksaan dalam rangka memenuhi syarat-syarat keselamatan bagi yang menempati bangunan tersebut.

2) Retribusi lzin Tempat Penjualan Minuman Beralkohol Izin tempat penjualan minuman beralkohol adalah pemberian izin untuk melakukan penjualan minuman beralkohol di suatu tempat tertentu. 
3) Retribusi lzin Gangguan

Izin gangguan adalah pemberian izin tempat usaha/kegiatan kepada orang pribadi atau badan di lokasi tertentu yang dapat menimbulkan bahaya, kerugian atau gangguan, tidak termasuk tempat usaha/kegiatan yang telah ditentukan oleh Pemerintah Pusat atau Pemerintah Daerah.

4) Retribusi Izin Trayek

Izin trayek adalah pemberian izin kepada orang pribadi atau badan usaha untuk menyediakan pelayanan angkutan penumpang umum pada suatu atau beberapa trayek tertentu. Pemberian izin oleh Pemerintah Daerah dilaksanakan sesuai dengan kewenangan masing-masing daerah.

\section{Retribusi Pasar}

Retribusi menurut Peraturan Pemerintah Nomor 28 tahun 2009 adalah pungutan daerah sebagai pembayaran jasa atau pemberian izin tertentu yang khusus disediakan dan/atau diberikan oleh Pemerintah Daerah (Pemda) untuk kepentingan pribadi atau badan. Menurut Mardiasmo (2007), retribusi adalah iuran kepada pemerintah yang dapat dipaksakan dan mendapatkan jasa balik secara langsung yang dapat ditunjuk. Paksaan yang dimaksud dalam retribusi ini tidak hanya bersifat ekonomis, melainkan memuat pula paksaan secara yuridis berupa sanksi administrasi maupun sanksi kepidanaan. Sebagai salah satu contoh dari retribusi adalah retribusi pasar. Menurut Peraturan Daerah Kota Bengkulu Nomor 07 Tahun 2013, Retribusi pasar adalah sejumlah pembayaran uang yang dipungut atas jasa pemakaian fasilitas pasar. Fasilitas yang dimaksud seperti Pelataran, Kios dan Los. Pelataran adalah lahan terbuka yang berada dalam lingkungan pasar dalam radius tertentu yang ditetapkan oleh Walikota dan dapat digunakan sebagai tempat berjualan oleh pedagang kaki lima; Kios adalah bangunan di dalam pasar yang beratap dan dipisahkan satu dengan yang lainnya dengan dinding pemisah mulai dari lantai sampai dengan langit-langit yang dipergunakan untuk usaha berjualan; Los adalah bangunan tetap di dalam pasar berbentuk bangunan memanjang tanpa dilengkapi dinding. Retribusi pasar itu sendiri merupakan pungutan retribusi atas jasa pelayanan penyediaan fasilitas pasar tradisional yang dikelola Pemerintah Daerah dan khusus disediakan untuk pedagang.

Retribusi pasar merupakan salah satu Retribusi Daerah yang termasuk dalam jenis Retribusi Jasa Umum. Karena itu dalam retribusi pasar, prinsip dan sasaran dalam penetapan struktur dan besarnya tarif retribusi pasar didasarkan pada tujuan untuk memperoleh keuntungan yang layak sebagai pengganti biaya pengelolaan, biaya penyelenggaraan, biaya kebersihan dan biaya administrasi.

1. Objek Retribusi Pasar

Objek Retribusi Pasar adalah pelayanan penyediaan fasilitas pasar tradisional yang berupa kios, pelataran, los yang dikelola Pemerintah Daerah dan khusus disediakan untuk pedagang.

2. Subjek Retribusi Pasar

Subjek Retribusi adalah orang pribadi atau badan yang menggunakan, memanfaatkan, menikmati jasa pelayanan penyediaan fasilitas pasar. Yang dimaksud dengan badan adalah suatu bentuk usaha yang meliputi Perseroan Terbatas, perseroan komanditer, Badan Usaha Milik Negara, firma, koperasi.

\section{KERANGKA ANALISIS}

Agar memudahkan pemahaman dalam penelitian ini, maka perlu dibuat kerangka analisis seperti ditunjukkan pada gambar 1. Gambar 1 menjelaskan alur penelitian yakni mengkaji sumber potensi retribusi di empat pasar umum di kota Bengkulu yaitu Pasar Panorama, Pasar Minggu, Pasar Baru Koto, dan Pasar Pagar Dewa. Potensi retribusi pasar umum diperoleh dengan mengidentifikasi fasilitas yang dimiliki dan potensi yang diharapkan dari empat pasar tersebut melalui fasilitas kios, los dan pelataran.

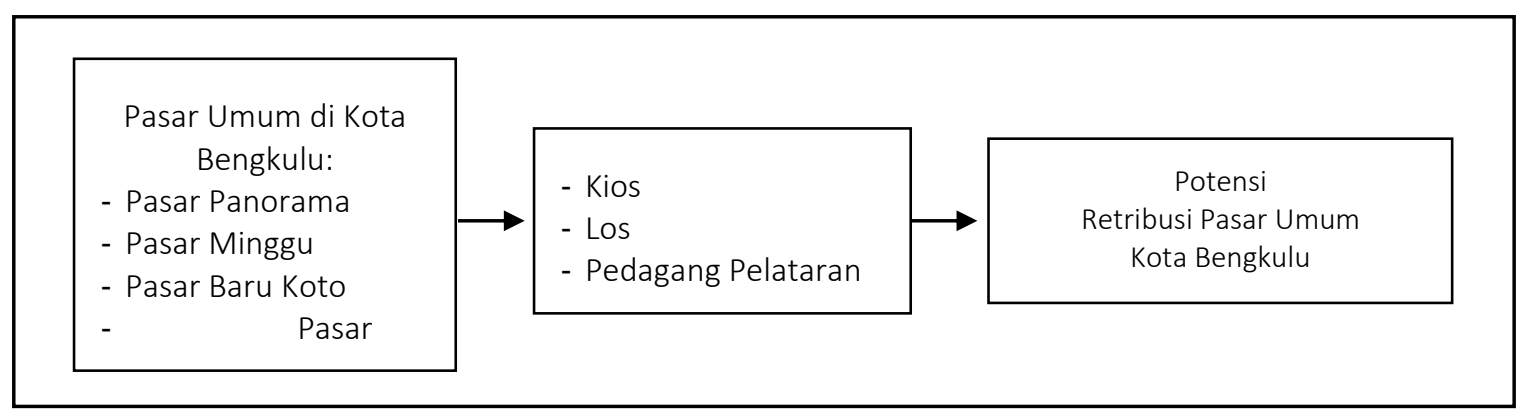

Gambar 1. Kerangka Analisis 


\section{METODOLOGI}

Teknik pengumpulan data dalam penelitian ini menggunakan dokumentasi. Data sekunder berupa potensi dan realisasi retribusi pasar umum di kota Bengkulu diperoleh dari Dinas Perindustrian dan Perdagangan Kota Bengkulu. Dalam menganalisis potensi retribusi pasar umum di kota Bengkulu, digunakan rumus potensi retribusi pasar menurut Mahmudi (2010) sebagai berikut:

$P R P U=\{(L L S \times T R)+(L K S \times T R)+(P R L S \times T R)+(J P K S \times T R)+$

$($ JPEP $\times$ TR) $\} \times\{($ Aktivitas Pasar Sebulan $\times 12)\}$

$\begin{array}{ll}\text { Keterangan: } \\ \text { PRPU } & =\text { Potensi Retribusi Pasar Umum } \\ \text { LLS } & =\text { Luas Los } \\ \text { LKS } & =\text { Luas Kios } \\ \text { PRLS } & =\text { Jumlah Pedagang Los } \\ \text { JPKS } & =\text { Jumlah Pedagang Kios } \\ \text { JPEP } & =\text { Jumlah Pedagang Pelataran } \\ \text { TR } & =\text { Tarif Retribusi }\end{array}$

Selanjutnya, untuk melihat pertumbuhan atas potensi dan penerimaan retribusi pasar menurut Mahmudi (2010) dengan rumus sebagai berikut:

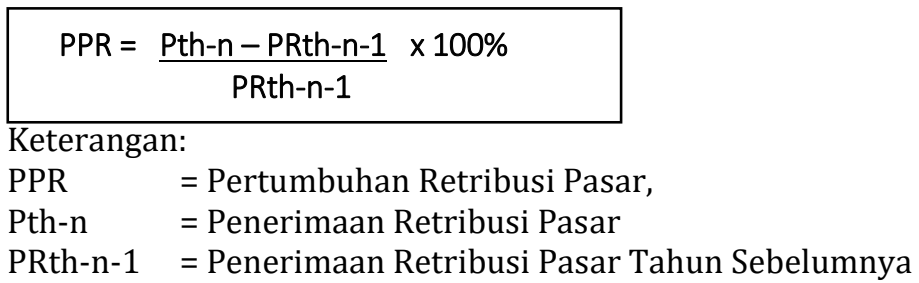

\section{HASIL PENELITIAN DAN PEMBAHASAN}

Potensi retribusi daerah adalah kekuatan yang ada disuatu daerah untuk menghasilkan sejumlah penerimaan retribusi daerah. Salah satu sumber retribusi daerah adalah retribusi pasar. Kota Bengkulu memiliki beberapa pasar dengan berbagai tipe yang merupakan salah satu sumber penerimaan retribusi daerah yang potensial dan diharapkan dapat memberikan potensi terhadap pendapatan daerah dan sesuai koridor peraturan perundang-undangan. Oleh karena itu sangat penting dukungan penguatan pendapatan dari objek-objek retribusi yang dipungut sebagai imbalan pemakaian jasa fasilitas pasar.

\section{Pasar yang dipungut retribusi yang ada di kota Bengkulu adalah:}

a. Pasar Panorama

Pasar ini terletak di kecamatan Singaran Pati Kota Bengkulu. Pasar ini cukup luas dan lebih nampak sebagai pasar tradisional. Pedagang berjualan memenuhi area pasar dengan lapak dan kios-kios sederhana. Pasar Panorama beroperasi hampir 24 jam. Kegiatan jual beli antara masyarakat dengan pedagang berlangsung mulai pukul 04.00 wib s/d 18.00 WIB. Setelah itu hingga pukul 04.00 WIB berlangsung kegiatan jual beli antara pemasok komoditi pasar dalam skala besar pada pedagang yang akan menjual kembali komoditi tersebut.

b. Pasar Minggu

Pasar Minggu atau bisa disebut pasar subuh ini juga memiliki letak strategis yaitu membutuhkan waktu 5 menit dari pusat kota. Aktivitas pasar ini dimulai dari jam 5 subuh hinga jam 6 sore akses menuju ke pasar minggu bisa ditembuh dengan kendaraan pribadi maupun angkutan kota.

c. Pasar Baru Koto

Pasar ini terletak di kawasan pariwisata Kota Bengkulu. Pasar ini hanya beroperasi pada pagi hari saja, dan menjelang sore hari para pedagang berangsur menutup dagangannya. Pasar Barukoto terlihat bersih dan tidak becek, pedagang di pasar ini lebih tertib dan tertata sesuai dengan jenis dagangannya.

d. Pasar Pagar Dewa

Pasar ini terletak di Pagar Dewa Kota Bengkulu. Pasar ini hanya beroperasi pada pagi hari dan menjelang sore hari para pedagang berangsur menutup dagangannya. Akses menuju ke pasar pagar dewa bisa ditempuh dengan menggunakan kendaraan pribadi maupun angkutan kota. 
Mekanisme dan sanksi terkait dengan retribusi pasar di kota Bengkulu:

1. Mekanisme Prosedur Pemungutan Retribusi Pasar

Dalam pemungutan retribusi pasar, ada beberapa prosedur/mekanisme yang harus dilakukan, antara lain:

a. Prosedur Pemungutan Retribusi

Dalam pelaksanaan pemungutan retribusi, Disperindag menempatkan beberapa petugas pemungut retribusi. Beberapa petugas pemungut retribusi tersebut di kepalai oleh seorang kepala pasar yang ditempatkan di setiap pasar, kepala pasar tersebut diangkat oleh Kepala Disperindag Kota Bengkulu. Seorang kepala pasar bertugas untuk mengatur dan mengkoordinir setiap retribusi yang dipungut oleh petugas retribusi. Kepala pasar mempunyai wewenang penuh terhadap pasar yang dikelolanya. Pengawasan penarikan retribusi oleh kepala pasar sangat penting dilakukan supaya petugas retribusi tidak sewenang-wenang dalam memungut retribusi kepada pedagang. Retribusi pasar ditarik dari setiap pedagang karena pedagang melakukan usaha berdagang di pasar menggunakan fasilitas-fasilitas yang terdapat di pasar. Adapun fasilitas-fasilitas yang dimiliki pasar terdiri dari kantor pasar, loket pasar, tanah,los, kios, mushola, air, listrik, parkir, lokasi bongkar muat barang dagangan dan saluran air. Penetapan tarif retribusi pasar didasarkan pada kebijakan daerah dengan memperhatikan biaya penyediaan jasa, kemampuan masyarakat dan aspek keadilan. Selain beberapa hal tersebut di atas, maka penetapan tarif retribusi juga didasarkan pada kebijakan pemerintah dalam Peraturan Daerah kota Bengkulu No. 7 Tahun 2013 tentang Retribusi Pelayanan Pasar.

b. Pengurusan, Pengelolaan dan Pembinaan Pasar

Pasar dikelola dan dibina oleh Pemerintah Daerah melalui kepala pasar yang ditugaskan di setiap pasar. Pelaksanaan pasar pemerintah ditunjuk oleh Kepala Disperindag dan salah satu diantaranya ditetapkan sebagai Kepala Pasar. Kepala Pasar Pemerintah disamping mengurus dan mengelola pasar pemerintah juga mengelola pasar desa di wilayahnya dalam hal tertib administrasinya, Kepala pasar bertanggung jawab kepada Kepala Disperindag. Pembinaan tidak hanya dilakukan oleh Kepala Pasar, tetapi juga sering dilakukan oleh seksi keamanan dan seksi ketertiban. Pembinaan yang dilakukan adalah tentang tata ruang pasar supaya suasana pasar tidak terkesan berantakan sehingga memudahkan dalam pemungutan retribusi. Pembinaan ini dilakukan karena pedagang sering seenaknya dalam menggelardagangannya dan menimbulkan kesan semraut.

c. Tata Cara Pemungutan Retribusi

Retribusi dipungut oleh petugas KPP dengan menggunakan sistem official assessment, yaitu pemungutan berdasarkan Peraturan Daerah kota bengkulu No. 07 Tahun 2013 tentang Retribusi Pelayanan Pasar dengan sistem pemungutan secara langsung menggunakan benda berharga atau karcis. Bagi pedagang yang tidak membayar retribusi tepat pada waktunya, maka akan dikenakan sanksi administrasi sebesar 2 persen perbulan dari keseluruhan jumlah retribusi yang harus dibayar dan ditagih dengan Surat Tagihan Retribusi Daerah (STRD).

Dalam pemungutannya pedagang harus mematuhi peraturan-peraturan walikota sebagai berikut:

1) Pemungutan retribusi tidak dapat diborongkan.

2) Retribusi dipungut menggunakan SKRD atau dokumen lain yang dipersamakan.

3) Bentuk dan SKRD ditetapkan oleh walikota

Penjelasan singkat dari sistem laporan Retribusi Pasar, adalah sebagai berikut: melalui Pihak Disperindag Kota Bengkulu ditunjuklah beberapa petugas khusus untuk memungut retribusi di pasar, mereka bertugas menarik retribusi. Kemudian uang hasil penarikan diserahkan dan dilaporkan langsung kepada Kepala Pasar, dan selanjutnya disetorkan ke Disperindag kota Bengkulu. Uang retribusi tersebut akan dikumpulkan, dihitung dan dicatat oleh Pembantu Bendaharawan Khusus Penerima(PBKP). Setelah penghitungan dan pencatatan selesai maka PBKP tersebut menyetorkan seluruh uang retribusi ke Bendahara Khusus Penerima yang ditanda tangani oleh Dinas perindustrian dan perdagangan Kepala Pasar 1234 Pemungut Retribusi. Setelah itu proses pemungutan retribusi pasar sampai pada tahap akhir yaitu penyetoran kepada kas daerah. Sistem Laporan Retribusi Pasar di wilayah Kota Bengkulu adalah sebagai berikut.

1) Pemungutan Retribusi mempunyai tugas memungut retribusi kepada pedagang di pasar, baik yang ada di dalam area pasar ataupun yang berada di rayon pasar, selanjutnya melaporkan hasil pungutan pasar tersebut kepada kepala pasar yang bertindak sebagai koordinator di lapangan disertai dengan surat tanda bukti setoran.

2) Koordinator atau Kepala Pasar mempunyai tugas mengumpulkan, menerima dan menyimpan setoran dari para pemungut retribusi, lalu menyetorkannya ke Disperindag. Uang retribusi tersebut dikumpulkan oleh pembantu bendaharawan khusus pada Dinas perindustrian dan perdagangan. 
3) PBKP-KPP (Pembantu Bendaharawan Khusus Penerima-Kantor Pelayanan Pasar) ini bertugas mengumpulkan, menghitung dan mencatat semua uang retribusi yang masuk dari seluruh pasar yang disetorkan oleh masing-masing kepala pasar. Setelah perhitungan dan pencatatan selesai maka PBKP tersebut menyetorkan seluruh uang retribusi ke Bendaharawan Khusus Penerima yang ditangani oleh Disperindag PBKP harus menyetorkan uang retribusi pasar selambat-lambatnya 6 hari kerja.

4) BKP (Bendahara Khusus Penerima) mempunyai tugas menerima semua hasil pungutan retribusi yang dikumpulkan oleh Pembantu Bendaharawan Khusus Penerima yang berkedudukan di Disperindag Kota Bengkulu.

5) Kas Daerah adalah tempat dimana uang hasil setoran retribusi pasar tersebut diterima sebagai bagian dari Pendapatan Asli Daerah (PAD)

d. Tata Cara Penyetoran

Walikota selaku Kepala Daerah telah menetapkan tanggal jatuh tempo penyetoran retribusi terutang paling lama 30 hari setelah saat terutang. Penyetoran dapat dilakukanlangsung ke BPD selaku pemegang kas daerah ataupun melalui Kantor Pengelolaan Pasar selaku instansi yang ditunjuk. Penyetoran dilakukan sesuai dengan waktu yang telahditentukan dengan menggunakan SKRD (Surat Ketetapan Retribusi Daerah) dan SKRDtambahan atau dokumen lain yang dipersamakan. Pembayaran harus disetorkan ke Kasdaerah selambat-lambatnya 1 x 24 jam atau dalam waktu yang ditentukan oleh walikota. Apabila penyetoran retribusi dilakukan setelah jatuh tempo maka wajib retribusiatau dikenakan STRD (Surat Tagihan Retribusi Daerah). Penyetoran harus dilakukan secara tunai. Penyetoran dapat dilakukan dengan izin tertulis dari Walikota atau Pejabat yang ditunjuk, dengan disertai alasan yang dapat dipertanggung jawabkan.

e. Tata Cara Penagihan

Penagihan dapat dilakukan pada wajib retribusi dengan menggunakan surat teguran atau surat peringatan sebagai awal tindakan penagihan yang dikeluarkan tujuh hari sejak awal jatuh tempo. Dalam waktu yang ditentukan wajib retribusi harus melunasi retribusiyang terutang. Surat Tagihan ini dikeluarkan oleh walikota.

f. Tata Cara Perhitungan Dan Pengembalian Retribusi

Apabila terjadi kelebihan pembayaran retribusi maka wajib retribusi dapat mengajukan permohonan secara tertulis kepada Walikota selaku Kepala Daerah. Kelebihan pembayaran retribusi tersebut dapat diperhitungkan secara langsung terlebih dahulu dengan utang retribusi atau sanksi administrasi berupa bunga. Kemudian baru diperhitungkan dengan pembayaran retribusi selanjutnya. Dalam pengembalian ini walikota akan menerbitkan (Surat Ketetapan Retribusi Daerah Lebih Baya (SKRDLB)sesuai dengan Peraturan Daerah kota Bengkulu Nomor 07 Tahun 2013 tentang Retribusi Pelayanan Pasar, pada (pasal 20) ayat (1) paling lambat 6 bulan sejak Diterimanyapermohonan pengembalian kelebihan pembayaran retribusi.

2. Sanksi bagi wajib retribusi yang terlambat melakukan pembayaran

Sanksi yang diberikan berdasarkan perda kota Bengkulu No. 07 tahun 2013 berupa:

a. Sanksi administrasi berupa bunga atau denda sebesar 2\% (dua persen) setiap bulan dari besar retribusi yang terutang/ tidak dibayar dan ditagih dengan mengunakan Surat Tagihan Retribusi Daerah ( STRD).

b. Wajib retribusi yang tidak melaksanakan kewajibannya sehinga merugikan keuangan daerah diancam dengan pidana kurungan selama-lamanya 3(tiga) bulan atau denda paling banyak 3(tiga) kali jumlah retribusi terutang yang tidak atau kurang dibayar.

\section{Potensi Penerimaan Retribusi Pasar di Kota Bengkulu}

Untuk meningkatkan potensi penerimaan retribusi pasar di Kota Bengkulu pada tahun 2016, ada beberapa hal yang perlu diperhatikan yaitu:

a. Tarif retribusi pasar

Tarif untuk retribusi pasar harus sesuai dengan Peraturan Daerah Kota Bengkulu No. 07 Tahun 2013 tentang Retribusi Pelayanan Pasar.

b. Jumlah pasar atau sarana fisik

Pasar di kota bengkulu berjumlah 4 pasar masing-masing pasar tersebut mempunyai wilayah kerja, fasilitas berupa kios, los, dan pelataran .

c. Jasa pasar yang disediakan

Pasar pelayanan barang publik oleh Pemda kota Bengkulu untuk berjualan terdiri dari kios, los permanen dengan dinding lantai bertegel, adanya lahan parkir, tersedianya MCK dan tersedianya petugas keamanan serta tersedianya bak penampungan sampah dan bongkar muat barang. 
Dalam mengkaji potensi retribusi pasar di kota Bengkulu, mengacu pada rumus potensi retribusi pasar menurut Mahmudi (2010). Namun, untuk mempermudah kajian analisis potensi retribusi pasar di kota Bengkulu, nilai potensi ditunjukkan dalam bentuk tabel dan telah disajikan dalam kurun waktu per tahun. Sehingga, potensi retribusi masing-masing pasar di kota Bengkulu ditunjukkan pada tabel berikut:

Tabel 1. Potensi Retribusi Pasar Panorama Tahun 2014-2016

\begin{tabular}{|c|c|c|c|c|c|c|c|c|c|}
\hline \multirow[b]{2}{*}{ Keterangan } & \multicolumn{3}{|c|}{2014} & \multicolumn{3}{|c|}{2015} & \multicolumn{3}{|c|}{2016} \\
\hline & Unit & $\begin{array}{l}\text { Tarif } \\
\text { (Rp) }\end{array}$ & $\begin{array}{c}\text { Jumlah } \\
\text { (Rp) }\end{array}$ & Unit & $\begin{array}{l}\text { Tarif } \\
\text { (Rp) }\end{array}$ & $\begin{array}{c}\text { Jumlah } \\
\text { (Rp) }\end{array}$ & Unit & $\begin{array}{l}\text { Tarif } \\
\text { (Rp) }\end{array}$ & $\begin{array}{c}\text { Jumlah } \\
\text { (Rp) }\end{array}$ \\
\hline Kios luas 12.3 & 1 & $1,328,400$ & $1,328,400$ & 1 & $1,328,400$ & $1,328,400$ & 1 & $1,328,400$ & $1,328,400$ \\
\hline Kios luas 12 & 356 & $1,296,000$ & $461,376,000$ & 356 & $1,296,000$ & $461,376,000$ & 356 & $1,296,000$ & $461,376,000$ \\
\hline Kios luas 9 & 160 & 972,000 & $155,520,000$ & 160 & 972,000 & $155,520,000$ & 160 & 972,000 & $155,520,000$ \\
\hline Kios luas 3.9 & 1 & 421,000 & 421,000 & 1 & 421,000 & 421,000 & 1 & 421,000 & 421,000 \\
\hline Los luas 3 & 1050 & 235,800 & $247,590,000$ & 1050 & 235,800 & $247,590,000$ & 1151 & 235,800 & $271,405,800$ \\
\hline Jumlah & & & $866,235,400$ & & & $866,235,400$ & & & $896,855,200$ \\
\hline
\end{tabular}

Sumber: Disperindag Kota Bengkulu, 2017 (data diolah)

Pasar Panorama merupakan salah satu pasar umum di kota Bengkulu dengan potensi penerimaan retribusi pasar terbesar. Selama periode pengamatan, rata-rata potensi penerimaan retribusi pasar mencapai Rp 876.442.000,- atau memilik kontribusi sebesar 39,47\% dari rata-rata potensi retribusi pasar umum di kota Bengkulu. Kontribusi terbesar dari potensi retribusi di pasar Panorama berasal dari penerimaan kios dengan luas $12 \mathrm{M}^{2}$ sebanyak 356. Dari tahun 2014 hingga tahun 2016, kios ini memiliki potensi penerimaan retribusi mencapai Rp 461.376.000,-. Pada tahun 2016, kios ini memberi potensi kontribusi hingga 51,44\%. Potensi penerimaan retribusi pasar Panorama mengalami pertumbuhan positif pada tahun 2016 mencapai 3,53\% dari tahun sebelumnya. Pertumbuhan tersebut disebabkan oleh adanya penambahan jumlah unit los dengan luas $3 \mathrm{M}^{2}$ sebanyak 101 unit dari tahun sebelumnya. Selanjutnya, Potensi penerimaan retrubusi pasar Minggu kota Bengkulu ditunjukkan pada tabel 3.

Tabel 3. Potensi Retribusi Pasar Minggu Tahun 2014-2016

\begin{tabular}{|c|c|c|c|c|c|c|c|c|c|}
\hline \multirow[b]{2}{*}{ Keterangan } & \multicolumn{3}{|c|}{2014} & \multicolumn{3}{|c|}{2015} & \multicolumn{3}{|c|}{2016} \\
\hline & Unit & $\begin{array}{l}\text { Tarif } \\
\text { (Rp) }\end{array}$ & $\begin{array}{l}\text { Jumlah } \\
\text { (Rp) }\end{array}$ & Unit & $\begin{array}{l}\text { Tarif } \\
\text { (Rp) }\end{array}$ & $\begin{array}{c}\text { Jumlah } \\
\text { (Rp) }\end{array}$ & Unit & $\begin{array}{l}\text { Tarif } \\
\text { (Rp) }\end{array}$ & $\begin{array}{l}\text { Jumlah } \\
\text { (Rp) }\end{array}$ \\
\hline Kios luas 36.7 & 6 & $3,969,000$ & $23,814,000$ & 6 & $3,969,000$ & $23,814,000$ & 6 & $3,969,000$ & $23,814,000$ \\
\hline Kios luas 30 & 3 & $3,240,000$ & $9,720,000$ & 3 & $3,240,000$ & $9,720,000$ & 3 & $3,240,000$ & $9,720,000$ \\
\hline Kios luas 27.5 & 1 & $2,972,160$ & $2,972,160$ & 1 & $2,972,160$ & $2,972,160$ & 1 & $2,972,160$ & $2,972,160$ \\
\hline Kios luas 20 & 2 & $2,160,000$ & $4,320,000$ & 2 & $2,160,000$ & $4,320,000$ & 2 & $2,160,000$ & $4,320,000$ \\
\hline Kios luas 18 & 38 & $1,944,000$ & $73,872,000$ & 38 & $1,944,000$ & $73,872,000$ & 38 & $1,944,000$ & $73,872,000$ \\
\hline Kios luas 15 & 2 & $1,620,000$ & $3,240,000$ & 2 & $1,620,000$ & $3,240,000$ & 2 & $1,620,000$ & $3,240,000$ \\
\hline Kios luas 14 & 2 & $1,512,000$ & $3,024,000$ & 2 & $1,512,000$ & $3,024,000$ & 2 & $1,512,000$ & $3,024,000$ \\
\hline Kios luas 12 & 27 & $1,296,000$ & $34,992,000$ & 27 & $1,296,000$ & $34,992,000$ & 27 & $1,296,000$ & $34,992,000$ \\
\hline Kios luas 10,5 & 55 & $1,134,000$ & $62,370,000$ & 55 & $1,134,000$ & $62,370,000$ & 55 & $1,134,000$ & $62,370,000$ \\
\hline Kios luas 9 & 130 & 972,000 & $126,360,000$ & 130 & 972,000 & $126,360,000$ & 144 & 972,000 & $139,968,000$ \\
\hline Kios luas 8.4 & 70 & 907,200 & $63,504,000$ & 70 & 907,200 & $63,504,000$ & 80 & 907,200 & $72,576,000$ \\
\hline Kios luas 7.5 & 60 & 810,000 & $48,600,000$ & 60 & 810,000 & $48,600,000$ & 60 & 810,000 & $48,600,000$ \\
\hline Kios luas 6 & 79 & 648,000 & $51,192,000$ & 79 & 648,000 & $51,192,000$ & 84 & 648,000 & $54,432,000$ \\
\hline Kios luas 4 & 5 & 432,000 & $2,160,000$ & 5 & 432,000 & $2,160,000$ & 5 & 432,000 & $2,160,000$ \\
\hline Los luas 6 & 42 & 471,600 & $19,807,200$ & 42 & 471,600 & $19,807,200$ & 42 & 471,600 & $19,807,200$ \\
\hline Los luas 4 & 255 & 314,400 & $80,172,000$ & 255 & 314,400 & $80,172,000$ & 255 & 314,400 & $80,172,000$ \\
\hline $\begin{array}{l}\text { Jumlah pedagang } \\
\text { Pelataran }\end{array}$ & 105 & 547,500 & $57,487,500$ & 98 & 547,500 & $53,655,000$ & 111 & 547,500 & $60,772,500$ \\
\hline Kios luas 36.7 & 6 & $3,969,000$ & $23,814,000$ & 6 & $3,969,000$ & $23,814,000$ & - & - & - \\
\hline Jumlah & & & $667,606,860$ & & & $663,774,360$ & & & $696,811,860$ \\
\hline
\end{tabular}

Sumber: Disperindag Kota Bengkulu, 2017 (data diolah)

Potensi retribusi pasar terbesar ke dua di kota Bengkulu setelah pasar Panorama adalah pasar Minggu. Rata-rata potensi penerimaan retribusi pasar dari tahun 2014 hingga tahun 2016 sebesar Rp 676.064.360,- per tahun atau memilik kontribusi sebesar 30,45\% dari rata-rata potensi retribusi pasar umum di kota Bengkulu. Pasar Minggu memiliki kios dengan ukuran luas yang cukup bervariasi. Kios dengan ukuran luas $9 \mathrm{M}^{2}$ memberi kontribusi terbesar dalam potensi penerimaan retribusi di pasar Minggu. Pada tahun 2016, kios ini memberi kontribusi sebesar Rp 139,968,000,- atau sebesar 20,08\%. Pada tahun 2016, potensi penerimaan retribusi pasar Minggu juga memiliki ertumbuhan positif yakni sebesar 4,98\% dari tahun sebelumnya. Hal tersebut disebabkan adanya penambahan beberapa unit kios seperti kios dengan ukuran luas $9 \mathrm{M}^{2}, 8,4 \mathrm{M}^{2}$, dan $6 \mathrm{M}^{2}$ dan jumlah pedagang pelataran dari 98 menjadi 111. Sedangkan kios dengan ukuran luas $36,7 \mathrm{M}^{2}$ tidak termasuk dalam potensi penerimaan retribusi, hal tersebut dikarenakan pada tahun 2016 kios tersebut sedang dalam renovasi.

Tabel 4 menunjukkan potensi penerimaan retribusi pasar Baru Koto kota Bengkulu tahun 2014 hingga tahun 2016. Pasar Baru Koto juga memiliki varian ukuran kios dan los yang bervariasi. Selama 
periode pengamatan, rata-rata potensi penerimaan retribusi pasar sebesar Rp 550.458.500,- per tahun atau memilik kontribusi sebesar $24,79 \%$ dari rata-rata potensi retribusi pasar umum di kota Bengkulu. Kontribusi terbesar dari potensi penerimaan retribusi pasar Baru Koto berasal dari kios dengan ukuran luas $20 \mathrm{M}^{2}$. Pada tahun 2016, kios ini menyumbang potensi penerimaan retribusi sebesar 23,39\%. Pada tahun 2016, potensi retribusi pasar Baru Koto juga memiliki pertumbuhan positif sebesar 8,79\% dari tahun sebelumnya. Hal tersebut disebabkan oleh adanya penambahan beberapa jumlah unit kios seperti kios ukuran $20 \mathrm{M}^{2}, 18,12 \mathrm{M}^{2}, 7,5 \mathrm{M}^{2}$, dan pedagang pelataran dari 100 menjadi 109. Selain itu, pada akhir tahun tahun 2015 terdapat beberapa penyelesaian proyek pembangunan kios baru yakni kios dengan ukuran luas $40 \mathrm{M}^{2}, 36,12 \mathrm{M}^{2}$, dan $16 \mathrm{M}^{2}$. Sehingga pada tahun 2016, kios tersebut sudah dapat beroperasi dan menjadi potensi penerimaan retribusi pasar Baru Koto.

Tabel 4. Potensi Retribusi Pasar Baru Koto Tahun 2014-2016

\begin{tabular}{|c|c|c|c|c|c|c|c|c|c|}
\hline \multirow[b]{2}{*}{ Keterangan } & \multicolumn{3}{|c|}{2014} & \multicolumn{3}{|c|}{2015} & \multicolumn{3}{|c|}{2016} \\
\hline & Unit & Tarif (Rp) & $\begin{array}{l}\text { Jumlah } \\
\text { (Rp) }\end{array}$ & Unit & Tarif (Rp) & $\begin{array}{l}\text { Jumlah } \\
\text { (Rp) }\end{array}$ & Unit & |Tarif (Rp) & $\begin{array}{l}\text { Jumlah } \\
\text { (Rp) }\end{array}$ \\
\hline Kios luas 40 & - & - & - & - & - & - & 1 & $4,320,000$ & $4,320,000$ \\
\hline Kios luas 36 & - & - & - & - & - & - & 1 & $3,888,000$ & $3,888,000$ \\
\hline Kios luas 22 & 9 & $2,376,000$ & $21,384,000$ & 9 & $2,376,000$ & $21,384,000$ & 9 & $2,376,000$ & $21,384,000$ \\
\hline Kios luas 20 & 59 & $2,160,000$ & $127,440,000$ & 59 & $2,160,000$ & $127,440,000$ & 63 & $2,160,000$ & $136,080,000$ \\
\hline Kios luas 18 & 48 & $1,944,000$ & $93,312,000$ & 48 & $1,944,000$ & $93,312,000$ & 51 & $1,944,000$ & $99,144,000$ \\
\hline Kios luas 16 & - & - & - & - & - & - & 1 & $1,728,000$ & $1,728,000$ \\
\hline Kios luas 15 & 2 & $1,620,000$ & $3,240,000$ & 2 & $1,620,000$ & $3,240,000$ & 2 & $1,620,000$ & $3,240,000$ \\
\hline Kios luas 12 & 30 & $1,296,000$ & $38,880,000$ & 30 & $1,296,000$ & $38,880,000$ & 38 & $1,296,000$ & $49,248,000$ \\
\hline Kios luas 10,8 & 3 & 972,000 & $2,916,000$ & 3 & 972,000 & $2,916,000$ & 3 & 972,000 & $2,916,000$ \\
\hline Kios luas 10 & 5 & $1,080,000$ & $5,400,000$ & 5 & $1,080,000$ & $5,400,000$ & 5 & $1,080,000$ & $5,400,000$ \\
\hline Kios luas 9 & 85 & 972,000 & $82,620,000$ & 85 & 972,000 & $82,620,000$ & 85 & 972,000 & $82,620,000$ \\
\hline Kios luas 8 & 9 & 864,000 & $7,776,000$ & 9 & 864,000 & $7,776,000$ & 9 & 864,000 & $7,776,000$ \\
\hline Kios luas 7,5 & 65 & 810,000 & $52,650,000$ & 65 & 810,000 & $52,650,000$ & 74 & 810,000 & $59,940,000$ \\
\hline Kios luas 6 & 5 & 648,000 & $3,240,000$ & 5 & 648,000 & $3,240,000$ & 5 & 648,000 & $3,240,000$ \\
\hline Los luas 9 & 44 & 707,500 & $31,130,000$ & 44 & 707,500 & $31,130,000$ & 44 & 707,500 & $31,130,000$ \\
\hline Los luas 6 & 8 & 471,000 & $3,768,000$ & 8 & 471,000 & $3,768,000$ & 8 & 471,000 & $3,768,000$ \\
\hline Los luas 4 & 20 & 314,400 & $6,288,000$ & 20 & 314,400 & $6,288,000$ & 20 & 314,400 & $6,288,000$ \\
\hline $\begin{array}{l}\text { Jumlah pedagang } \\
\text { Pelataran }\end{array}$ & 100 & 547,500 & $54,750,000$ & 100 & 547,500 & $54,750,000$ & 109 & 547,500 & $59,677,500$ \\
\hline Jumlah & & & $534,794,000$ & & & $534,794,000$ & & & $581,787,500$ \\
\hline
\end{tabular}

Sumber: Disperindag Kota Bengkulu, 2017 (data diolah)

Pasar Pagar Dewa merupakan salah satu pasar umum di kota Bengkulu yang memiliki potensi retribusi pasar yang relatif lebih rendah jika dibanding dengan pasar umum lainnya. Namun demikian, aktivitas yang berjalan di pasar ini cukup membantu kelancaran perekonomian masyarakat. Selama periode pengamatan, rata-rata potensi penerimaan retribusi pasar sebesar Rp 117.500.100,- per tahun atau memiliki kontribusi sebesar 5,29\% dari rata-rata potensi retribusi pasar umum di kota Bengkulu. Jika dilihat dari skala ukuran pasar, pasar Pagar Dewa merupakan pasar dengan ukuran paling kecil jika dibanding dengan pasar lainnya. Sehingga, hal tersebut juga turut mempengaruhi keterbatasan penyediaan jumlah kios, los maupun tempat pedagang pelataran. Tempat pedagang pelataran memiliki jumlah unit terbesar dibanding dengan kios dan los. Hal ini menjadikannya sebagai penyumbang terbesar atas potensi retribusi pasar. Pada tahun 2016, tempat pedagang pelataran yang disediakan sebanyak 55 unit dengan kontribusi sebesar Rp 30.112.500.

Tabel 5. Potensi Retribusi Pasar Pagar Dewa Tahun 2014-2016

\begin{tabular}{|c|c|c|c|c|c|c|c|c|c|}
\hline \multirow[b]{2}{*}{ Keterangan } & \multicolumn{3}{|c|}{2014} & \multicolumn{3}{|c|}{2015} & \multicolumn{3}{|c|}{2016} \\
\hline & Unit & Tarif (Rp) & $\begin{array}{c}\text { Jumlah } \\
\text { (Rp) }\end{array}$ & Unit & Tarif (Rp) & $\begin{array}{c}\text { Jumlah } \\
\text { (Rp) }\end{array}$ & Unit & Tarif (Rp) & $\begin{array}{c}\text { Jumlah } \\
\text { (Rp) }\end{array}$ \\
\hline Kios luas 20 & 6 & $2,160,000$ & $12,960,000$ & 6 & $2,160,000$ & $12,960,000$ & 6 & $2,160,000$ & $12,960,000$ \\
\hline Kios luas 15 & 13 & $1,620,000$ & $21,060,000$ & 13 & $1,620,000$ & $21,060,000$ & 13 & $1,620,000$ & $21,060,000$ \\
\hline Kios luas 12 & 6 & $1,296,000$ & $7,776,000$ & 6 & $1,296,000$ & $7,776,000$ & 6 & $1,296,000$ & $7,776,000$ \\
\hline Kios luas 10 & 10 & $1,080,000$ & $10,800,000$ & 10 & $1,080,000$ & $10,800,000$ & 10 & $1,080,000$ & $10,800,000$ \\
\hline Kios luas 9 & 16 & 972,000 & $15,552,000$ & 16 & 972,000 & $15,552,000$ & 16 & 972,000 & $15,552,000$ \\
\hline Kios luas 6 & 19 & 648,000 & $12,312,000$ & 19 & 648,000 & $12,312,000$ & 19 & 648,000 & $12,312,000$ \\
\hline Los luas 6 & 14 & 471,600 & $6,602,400$ & 14 & 471,600 & $6,602,400$ & 14 & 471,600 & $6,602,400$ \\
\hline Los luas 4 & 8 & 314,400 & $2,515,200$ & 8 & 314,400 & $2,515,200$ & 8 & 314,400 & $2,515,200$ \\
\hline Jumlah Pedagang Pelataran & 50 & 547,500 & $27,375,000$ & 48 & 547,500 & $26,280,000$ & 55 & 547,500 & $30,112,500$ \\
\hline Jumlah & & & $116,952,600$ & & & $115,857,600$ & & & $119,690,100$ \\
\hline
\end{tabular}

Sumber: Disperindag Kota Bengkulu, 2017 (data diolah)

Potensi retribusi pasar umum di kota Bengkulu juga ditunjukkan pada gambar 2. Gambar 2 menunjukkan bahwa secara umum terdapat dua pola potensi penerimaan retribusi yang berbeda pada 
pasar tersebut. Pasar Pagar Dewa dan pasar Minggu memiliki potensi penerimaan retribusi yang berfluktuasi. Secara bersamaan, pada tahun 2015 terjadi penurunan potensi penerimaan retribusi pasar. Pasar Pagar Dewa mengalami pertumbuhan negatif sebesar $-0,94 \%$ dari tahun sebelumnya, demikian halnya pasar Minggu juga mengalami pertumbuhan negatif sebesar $-0,57 \%$ dari tahun sebelumnya. Pertumbuhan negatif di pasar Pagar Dewa disebabkan oleh adanya perbaikan sebagian tempat berdagang bagi pedagang pelataran. Namun selanjutnya, setelah dilakukan renovasi dan penambahan unit bagi pedagang pelataran, potensi retribusi pasar Pagar Dewa meningkat pada tahun 2016 atau mengalami pertumbuhan positif sebesar 3,31\%. Hal yang sama juga terjadi di pasar Minggu. Pertumbuhan negatif pada tahun 2015 juga disebabkan oleh adanya renovasi dan penambahan unit bagi pedagang pelataran.

Berbeda dengan pasar Pagar Dewa dan pasar Minggu, pasar Panorama dan pasar Baru Koto mengalami pertumbuhan positif atas potensi penerimaan retribusi pasar. Dengan kondisi yang sama, pada tahun 2014 dan 2015, tidak terjadi peningkatan atau penurunan jumlah fasilitas ke dua pasar tersebut baik kios, los maupun jumlah pedagang pelataran. Namun, pada tahun 2016 terjadi pertumbuhan positif. Pertumbuhan positif di pasar Panorama disebabkan oleh adanya penambahan jumlah pedagang pelataran. Sedangkan pertumbuhan positif di pasar Baru Koto disebabkan adanya penambahan jumlah unit kios dan jumlah pedagang pelataran.

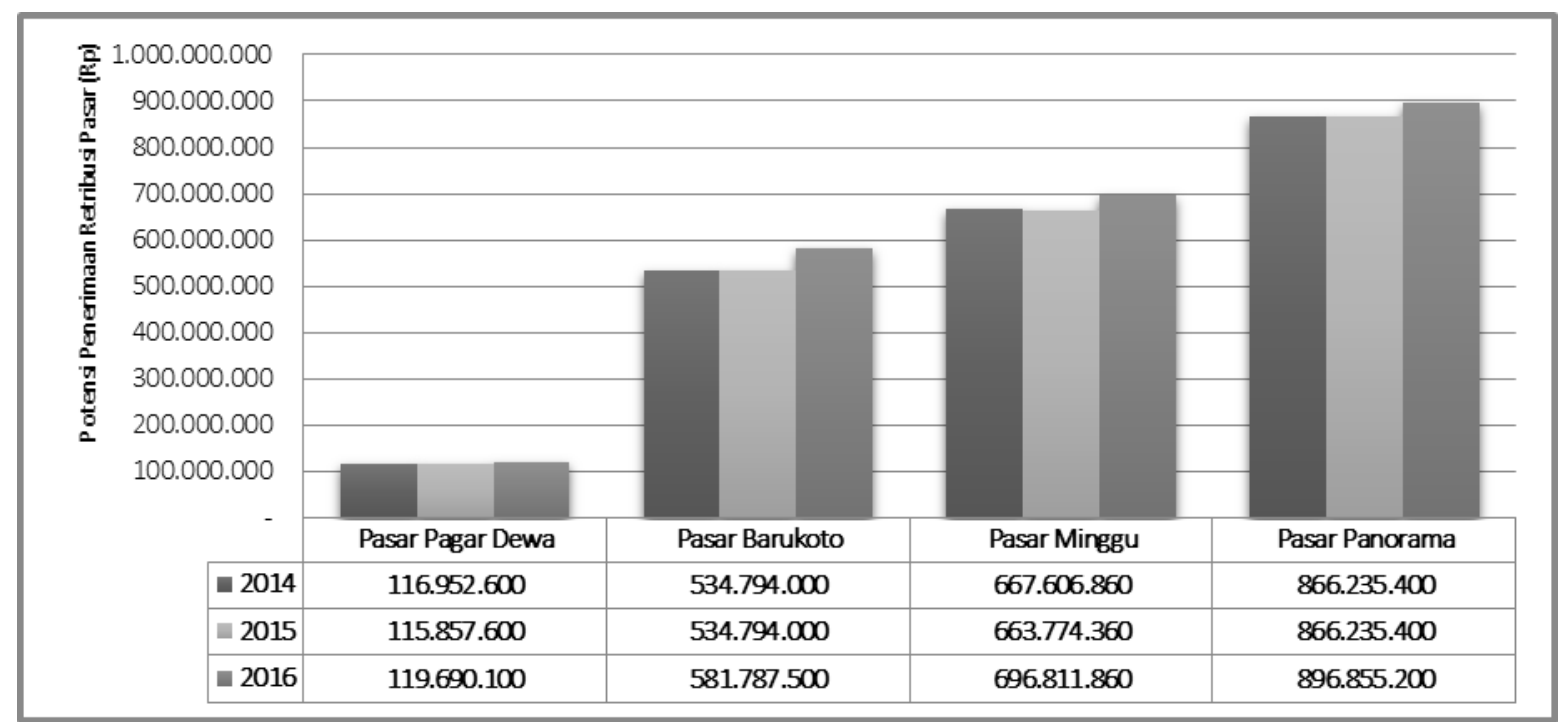

Gambar 2. Potensi Penerimaan Retribusi Pasar Umum di Kota Bengkulu

Selanjutnya, gambar 3 menunjukkan perbandingan antara potensi dan realisasi penerimaan retribusi pasar umum di Kota Bengkulu tahun 2014 hingga tahun 2016. Selama periode pengamatan, capaian realisasi masih berada di bawah potensi yang dimiliki. Persentase capaian realisasi terhadap potensi penerimaan retribusi pasar umum di kota Bengkulu secara berturut-turut dari tahun 2014 hingga tahun 2016 masing-masing sebesar 82,08\%, 80,23\% dan 88,07\% dengan rata-rata sebesar 83,53\% per tahun. Beberapa hambatan dalam pemungutan retribusi pasar di kota Bengkulu diantaranya adalah (a) Dari wajib retribusi itu sendiri yang kurang mempunyai kesadaran untuk melaksanakan pembayaran retribusi; (b) Masih banyaknya pedagang yang berjualan diluar lokasi pasar sehinga tidak dapat dipungut retribusi di karenakan diluar wewenang pegelola pasar. Namun, pemerintah daerah kota Bengkulu harus senantiasa berupaya meningkatkan realisasi penerimaan retribusi pasar umum dengan potensi yang dimiliki. Selanjutnya, strategi yang dilakukan oleh pemerintah untuk meningkatkan pendapatan pasar adalah (a) Menyiapkan sarana dan prasarana yang memadai untuk para pedagan; (b) Berkoordinasi dengan instansi terkait untuk menertibkan pedagang yang berjualan di luar lokasi pasar; (c) Menata tempat pedagang dengan baik; (d) Menciptakan suasana yang aman dan bersih dilingkungan pasar. 


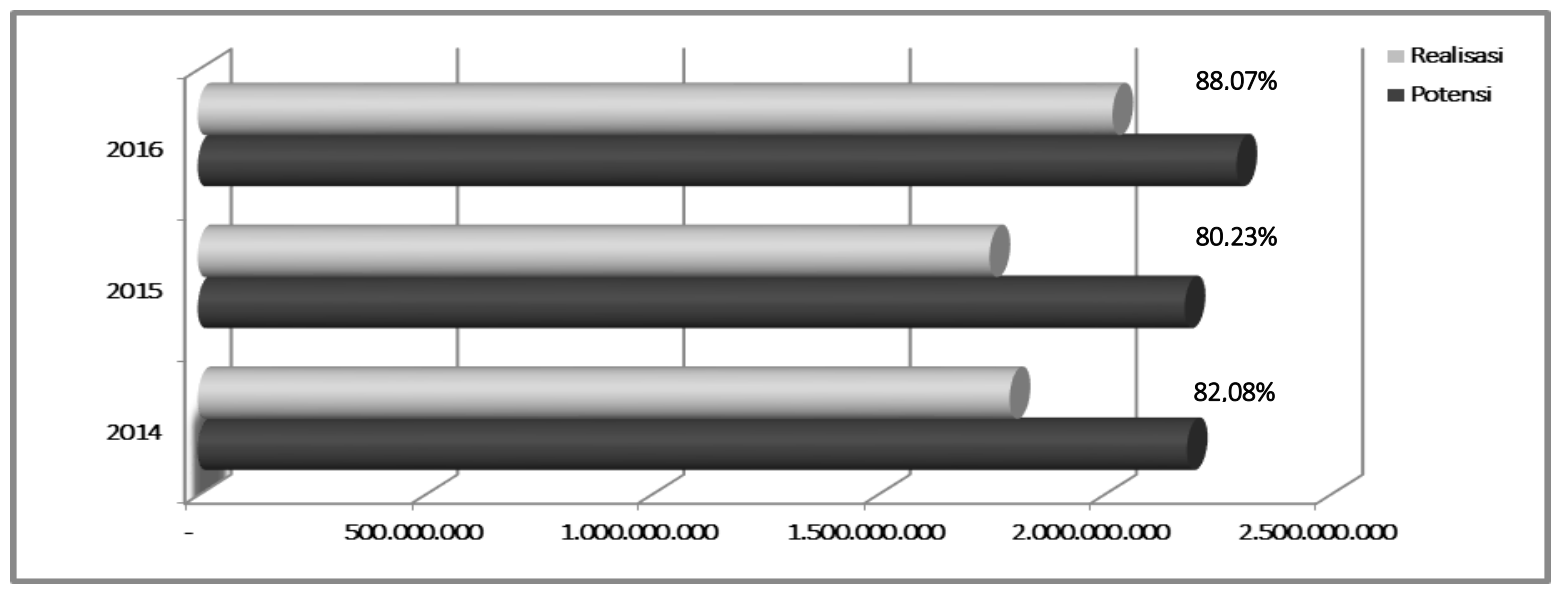

Gambar 3. Potensi dan Realisasi Penerimaan Retribusi Pasar Umum di Kota Bengkulu

\section{KESIMPULAN}

Berdasar hasil kajian dan pembahasan yang telah diuraikan di atas, maka penulis dapat menyimpulkan bahwa potensi pasar yang ada di Kota Bengkulu secara umum mengalami fluktuasi. Ratarata potensi penerimaan retribusi pasar umum sebesar $\mathrm{Rp} 2.220 .464 .960$,- per tahun dengan rata-rata pertumbuhan sebesar 2,51\% per tahun. Hal tersebut seiring dengan realisasi retribusi pasar umum yang juga mengalami fluktuasi. Rata-rata realisasi penerimaan retribusi pasar umum sebesar Rp 1.854.906.535,- dengan rata-rata pertumbuhan sebesar 6,53\% per tahun. Persentase capaian realisasi terhadap potensi penerimaan retribusi pasar umum di kota Bengkulu secara berturut-turut dari tahun 2014 hingga tahun 2016 masing-masing sebesar 82,08\%, 80,23\% dan 88,07\% dengan rata-rata sebesar $83,53 \%$ per tahun. Prestasi capaian rata-rata di atas $80 \%$ ini dianggap baik. Namun, pemerintah daerah kota Bengkulu harus senantiasa berupaya meningkatkan realisasi penerimaan retribusi pasar umum dengan potensi yang dimiliki dengan mengatasi hambatan yang ada dan mencapai strategi yang dijalankan.

\section{DAFTAR PUSTAKA}

Mahmudi. 2010. Manajemen Keuangan Daerah. Jakarta: Erlangga.

Mardiasmo. 2007. Otonomi \& Manajemen Keuangan Daerah. Yogyakarta: Andi.

Peraturan Pemerintah No. 28 Tahun 2009 Tentang Pajak Daerah Dan Retribusi Daerah.

Peraturan Daerah Kota Bengkulu Nomor 7 Tahun 2013 Tentang Retribusi Pelayanan Pasar

Realisasi Penerimaan Retribusi Pasar Kota Bengkulu. 2017. Dinas Perindustrian dan Perdagangan Kota Bengkulu.

Siahaan, P Marihot. 2010. Pajak Daerah Dan Retribusi Daerah. Jakarta: Rajawali.

Simamora, Bilson. 2008. Panduan Riset Prilaku Konsumen Cetakan Ketiga. Jakarta: Gramedia Pustaka Utama. 